\title{
Tax Treaties, Renegotiations, and Foreign Direct Investment
}

\author{
Ronald B. Davies ${ }^{1}$
}

University of Oregon

April 2003

Revised Version: June 2003

\begin{abstract}
Bilateral tax treaties are an important method of international tax cooperation. I survey the existing literature on these agreements, highlighting the differences between the standard view that treaties increase foreign direct investment and the empirical evidence that finds no such effect. I also provide new empirical results on the impact of renegotiations on foreign direct investment. I find that, comparable to other empirical studies on tax treaties, renegotiations have no robust positive impact on FDI.
\end{abstract}

JEL Classification: F21, F23, H25

Key Words: Foreign Direct Investment, Tax Treaties, Multinational Corporations

\footnotetext{
${ }^{1}$ Department of Economics, 435 PLC Building, 1285 University of Oregon, Eugene, OR 97403 USA; Phone: +1 (541) 346-4671; Fax: +1 (541) 346-1243; E-mail: rdavies@oregon.uoregon.edu.
} 


\section{Introduction}

Foreign direct investment (FDI) is becoming ever more important to the global economy. During the 1990s sales by foreign affiliates grew by approximately 11 percent (Markusen, 2002). This was nearly twice the growth rate of exports and almost four times that of worldwide GDP. Correspondingly, researchers have increasingly devoted attention to the driving forces behind multinational enterprises (MNEs). ${ }^{2}$ At the same time, they have studied the government policies used to manipulate FDI especially the strategic use of taxation. ${ }^{3}$ More recently, attention has shifted from competitively set taxes to the cooperative coordination afforded under bilateral tax treaties (also known as double taxation agreements and treaties covering the taxation of investment and income). ${ }^{4}$ Worldwide, over 2,000 of these bilateral treaties are in place and they govern the large majority of FDI (Radaelli, 1997). ${ }^{5}$ Recently, additional interest has been sparked by the announced relocation of Australian firm James Hardie in response to the renegotiation of the U.S./Netherlands treaty. Thus, the time is ripe for both a brief survey of the economic research on tax treaties as well as initial results regarding the effect of treaty renegotiations on FDI.

Since tax treaties are used by a variety of countries and are applied to a spectrum of investment activities, they exhibit a large degree of heterogeneity. Nevertheless, almost all treaties claim to remove tax barriers to investment. This creates the expectation that treaties increase FDI. While the exact provisions used to do this vary, most treaties loosely follow the recommendations of the model tax agreements provided by the Organization for Economic Cooperation and Development (OECD, 1997) and the United Nations (UN, 2001). ${ }^{6}$ A key barrier

\footnotetext{
${ }^{2}$ Caves (1993) and Markusen (2002) supply comprehensive overviews of the FDI literature.

${ }^{3}$ See Wilson (1999) and Gresik (2001) for recent surveys of the tax competition literature.

${ }^{4}$ As noted by Easson (1999) double tax agreements are different creatures than bilateral investment treaties. These latter agreements work to promote FDI by methods apart from taxation and to the extent that they do discuss tax measures, they are superceded by any relevant double taxation agreements.

${ }^{5}$ In addition to their provisions affecting FDI, treaties affect the taxation of portfolio investments and personal income.

${ }^{6}$ Many countries also have their own model treaties that mirror these agreements.
} 
treaties tackle is the double taxation of FDI. The introduction to the OECD's model treaty makes it clear that "removing the obstacles that double taxation presents" and reducing its "harmful effects on the exchange of goods and services and movements of capital, technology, and persons" is a primary goal. (OECD, 1997, p. I-1). ${ }^{7}$ This view is shared by Jones, who emphasizes the benefits of treaties, stating that, "There is no doubt in our minds that [treaties] do have an impact on both investment abroad by Australians and foreign investment in Australia" (Jones, 1996, pg. 21).

Empirical evidence, however, provides little support for this belief. Instead, the data suggest that treaties have either a zero or even a negative effect on FDI. Two primary explanations for this stand out. The first, originating with Hartman (1985), shows that investment in mature subsidiaries may be independent of the withholding tax reductions treaties achieve. The second focuses on a less-publicized goal of treaties: the reduction of tax evasion. Since some FDI may occur to facilitate transfer pricing, treaty provisions that hinder tax avoidance may reduce FDI. This view is popular with international tax lawyers such as Dagan (2000).

This paper proceeds as follows. In Section 2, I discuss the role of treaties in reducing double taxation. Section 3 summarizes the empirical evidence on treaties and FDI. In Section 4, I detail two FDI-reducing effects of tax treaties. In Section 5, I provide new evidence analyzing the effect of treaty revisions on U.S. FDI. Section 6 concludes.

\section{FDI-promoting Effects of Tax Treaties}

When analyzing tax treaties, economists have focused on their efficiency-enhancing properties. Treaties can increase investment in several ways. First, they work to offset the double taxation of foreign-earned profits. They do so by governing double taxation relief methods, reducing the withholding taxes, and coordinating definitions and jurisdictions across borders. In

\footnotetext{
${ }^{7}$ For a detailed discussion of the OECD model treaty, see Baker (1994).
} 
addition to this, treaties can reduce tax uncertainty. ${ }^{8}$ As Jones (1996) points out, even a treaty that merely codifies the current practice reduces uncertainty for investors by lowering the likelihood that a government will unilaterally change its tax policy. Treaties also reduce uncertainty by providing rules for dealing with tax conflicts between governments and between governments and firms (Gravelle, 1988). Since uncertainty can be a major barrier to investment, simply reinforcing and formalizing the tax environment can encourage investment. Given the stability of treaties between OECD members, this may be an important function of treaty formation (Sasseville, 1996).

To illustrate the problem and solutions to double taxation, consider the following simple model. There are two countries, home and host. Home is the parent country for an MNE that produces in both countries using capital and labor. At home, the MNE produces using the concave production function $h(K-Z, L)$ where $\mathrm{K}$ is its exogenously endowed capital stock, $\mathrm{Z}$ is its capital outflow (FDI), and L is its domestic labor input. Overseas, the MNE produces using the concave function $h^{s}\left(Z, L^{s}\right)$ where $\mathrm{L}^{\mathrm{s}}$ is the host labor it hires. The price of output is constant and equal to one. Home and host wages are w and $\mathrm{w}^{*}$, both of which the firm takes as given.

Profits earned at home are taxable only by home and are done so at rate t. Foreign-earned profits are potentially subject to both home and host taxation. The host tax rate is $\mathrm{t}^{*}$. Upon repatriation, these profits are taxable by home. The home statutory tax on overseas profits is $\mathrm{t}^{\mathrm{s}}$. If home practices uniform taxation, then $t^{s}=t .{ }^{9}$ Note that this is the statutory tax and not the actual tax paid to home since home may offer double taxation relief. Three primary relief methods are used: deductions, credits, and exemptions. Under deductions, the home government treats host taxes as a cost and taxes the after-host tax level of overseas profits. Under credits, the home

\footnotetext{
${ }^{8}$ Rajan and Marwah (1998) and Drabek and Payne (2002) find inhibiting effects of political instability on FDI that are suggestive of the impact tax uncertainty may have

${ }^{9}$ Uniformity is distinct from non-discrimination. This latter term implies that a country taxes income domestically-earned profits at the same rate regardless of whether they are earned by its own citizens or inbound MNEs. The OECD model treaty (1997) mandates non-discrimination. While many countries claim to follow this convention, evidence from Hines (1988) and Hufbauer (1992) indicates that in practice taxes are discriminatory.
} 
government calculates the firm's tax obligation using the pre-host tax level of overseas profits. It then offers a limited tax credit in the amount of the host tax bill. If the amount paid to the host is less than the domestic obligation, the firm is in an "excess limit" position and pays the difference to home. If the host taxes paid exceed the domestic obligation, the firm is in an "excess credit" position and pays no further taxes. Under exemptions, the firm pays no home tax on its overseas profits. Thus, the effective tax rate on overseas profits, $\mathrm{t}^{\mathrm{e}}$, is:

$$
1-t^{e}= \begin{cases}1-t^{s}-t^{*} & \text { if home offers no relief } \\ \left(1-t^{s}\right)\left(1-t^{*}\right) & \text { if home offers deductions } \\ 1-t^{*} & \text { if home offers exemptions } \\ 1-\max \left\{t^{s}, t^{*}\right\} & \text { if home offers credits. }\end{cases}
$$

Without relief, the cumulative taxes can be substantial. With no relief or treaty provisions, an Australian subsidiary paying dividends from its U.S. income would face a 34\% U.S. income tax, a $30 \%$ withholding tax, and a $36 \%$ Australian income tax, totaling $89.8 \%$. Comparing this to the $45.9 \%$ rate actually used illustrates the crucial role that double taxation relief plays.

In this one period model, all profits are repatriated. This yields MNE profits:

$$
\pi=(1-t)(h(K-Z, L)-w L)+\left(1-t^{e}\right)\left(h^{s}\left(Z, L^{s}\right)-w^{*} L^{s}\right) .
$$

The firm chooses its labor inputs and capital allocation to maximize (2). The first-order conditions are:

$$
\begin{gathered}
w=h_{l} \\
w^{*}=h_{l}^{s}
\end{gathered}
$$

and

$$
(1-t) h_{k}=\left(1-t^{e}\right) h_{k}^{s}
$$

From this, comparative statics can be computed, the most important of which is that FDI is decreasing in the relative effective tax rate $\mathrm{T}$, where $1-T=\frac{1-t^{e}}{1-t}$. The exact formula by which the tax rates and provisions used in practice translate into this relative effect tax depend on the tax 
rules imposed by the home and host governments and there exists an active debate on how to most appropriately make this conversion. ${ }^{10}$ In my model, I focus on the marginal tax rate differential between countries and the average tax rate of each country and, in the interest of brevity, ignore these considerations.

Governments choose taxes to maximize national income anticipating how this affects firm choices. ${ }^{11}$ Home national income is the sum of firm profits, labor income, and tax revenues:

$$
Y=h(K-Z, L)+w L+\left(1-t^{*}\right)\left(h^{s}\left(Z, L^{s}\right)-w^{*} L^{s}\right) .
$$

Host national income is the sum of labor income and tax revenues:

$$
Y^{*}=w^{*} L^{s}+t^{*}\left(h^{s}\left(Z, L^{s}\right)-w^{*} L^{s}\right)
$$

Summing (6) and (7) shows that taxes are a wash in world income and that global income is maximized under capital export neutrality, i.e. when capital is allocated without regard to international tax differences. ${ }^{12}$ By (5), this requires that $T=0$.

However, capital export neutrality usually fails in equilibrium. Since FDI represents a taxable base for the host, in the absence of home taxation host sets $t^{*}=\frac{1}{1+\varepsilon}$ where $\varepsilon \equiv \frac{-h_{k}}{Z h_{k k}}$ is the elasticity of FDI with respect to T. In addition, if home offers credits, by (1) host can always raise $t^{*}$ to $t^{\mathrm{s}}$ and increase tax revenues without decreasing FDI. Note that host views the overseas rate of return as elastic. Thus, contrary to models of small host countries such as Mintz and Tulkins (1986), host sets a positive tax on inbound FDI.

Since host taxes are a cost in (6), home prefers that $T \geq t^{*}$. If host wages are constant, home's optimal amount of FDI equates the pre-tax rate of return at home with the after-host tax

\footnotetext{
${ }^{10}$ See Giannini and Maggiulli (2002) for a recent example.

${ }^{11}$ This assumption is standard in the home-host tax competition literature. Examples include Bond and Samuelson (1989), Janeba (1995), and Davies (2003). This setup contrasts with the public good provision stories of host-host competition models such Wilson (1986) and Zodrow and Mieszkowski (1986). A common feature of host-host models is that tax competition results in inefficiently low taxes. Since tax treaties reduce taxes and are negotiated between a home and host, not two potential hosts, such models are not the most appropriate for analyzing treaties.

${ }^{12}$ Capital export neutrality is discussed by Bradford (1984) and Slemrod (1988).
} 
rate of return in the host. Thus, home sets $T=t^{*}>0$, resulting in inefficiently low FDI. If $t=0$, home can use credits and set $t^{s} \leq t^{*}$ or use exemptions. If $t>0$ home sets $t=t^{s}$ and offer deductions. As Hamada (1966) notes, when $t>0$, for given taxes T is reduced and FDI is increased by the use of credits or exemptions instead of deductions. Musgrave (1969) counters that home would nevertheless prefer deductions since credits or exemptions yield $T<t^{*}$.

This illustrates two early views on the role of tax treaties. First, treaties mandate either credits or exemptions. Since nations typically tax domestic profits, movement away from deductions may increase FDI. Second, many treaties lower withholding taxes which is equivalent to reducing $\mathrm{t}^{*}$. These reductions can be quite dramatic. For example, the non-treaty Australian withholding tax on dividend payments is 30 percent. Under many of its treaties, this is cut in half. Similarly, the withholding tax on royalties generally falls from 30 to 10 percent. Outside of excess limits this reduces $\mathrm{t}^{\mathrm{e}}$ and increases FDI. Several empirical studies, including Mutti (1981), Hines and Hubbard (1990), and Altshuler, Newlon, and Randolph (1995) confirm the negative effect of effective taxes on FDI.

A shortcoming of this approach is that taxes are constant. Bond and Samuelson (1989) endogenize discriminatory taxes and compare the equilibria under credits and deductions. ${ }^{13}$ They maintain the assumption that the MNE treats wages as fixed, but assume that the home government recognizes that host wages are increasing in $\mathrm{L}^{\mathrm{s}}$. Because the host wage is increasing in $\mathrm{L}^{\mathrm{s}}$, the MNE hires too much labor from the home government's perspective. To correct this, home sets $T>t^{*}$ reducing both $\mathrm{Z}$ and $\mathrm{L}^{\mathrm{s}}$. Under credits, this requires that $t^{s}>t^{*}$. Host optimal taxation remains as above where under credits it sets $t^{*} \geq t^{s}$. Combining these implies that tax competition under credits is so severe that taxes are pushed to a prohibitively high level. Best responses under deductions, however, only require that each country sets taxes that are positive

\footnotetext{
${ }^{13}$ Most models of tax competition assume taxes are set simultaneously. Feldstein and Hartman (1979) and Gordon (1992) derive equilibria when the capital exporter is a Stackelberg leader and find inefficiently low FDI.
} 
but not prohibitive. This yields positive if inefficient FDI, indicating that deductions are superior to credits. However, this analysis lacks something since many countries offer credits both with and without treaties and yet maintain positive capital outflows.

Davies and Gresik (2003) offer a possible reconciliation by demonstrating that with additional host sectors and factors, endogenous host factor prices are decoupled from taxes. Nevertheless, we also find that FDI is inefficiently low and that deductions are weakly preferable to credits from a global perspective. Janeba (1995) provides an alternative explanation by taking the Bond and Samuelson framework and imposing uniform taxation. As before, home wishes to set $T>t^{*}$ to induce favorable host factor prices changes. Under deductions, $T=t^{*}$ regardless of the home tax. Under credits or exemptions, with uniform taxation $T<t^{*}$ when $t>0$. Since taxes are constrained to be non-negative, Janeba finds that all three relief methods yield welfareequivalent equilibria with inefficiently low FDI.

Combining these results does not bode well for treaty formation since at best moving from deductions to credits has no impact of FDI. This, however, ignores tax rate coordination. Janeba (1995) shows that with tax harmonization, only under credits or exemptions is it possible to achieve both efficiency and mutual gains. Under these relief methods, setting $t=t^{*}$ implies that $T=0$ and FDI is efficient. By increasing this common tax rate, income is shifted from home to host without affecting FDI. Thus, there exists a range of harmonized tax rates that yield greater surplus for both countries with home preferring low taxes and host preferring high taxes. Under deductions, efficient FDI requires a zero host tax, making the host worse off relative to the competitive equilibrium. Thus, with uniform taxation, credits or exemptions, and tax coordination, mutually beneficial, efficient treaties exist.

In Davies (2003), I show that in some cases explicit tax coordination is not even necessary. There, I take the above model with a constant host wage and introduce two-way 
capital flows under uniform taxation and non-discrimination. ${ }^{14}$ Thus, each government imposes the same statutory tax rate on all income earned by its own citizens and on income earned by foreigners within its borders. Now, when a country uses credits or exemptions, a higher tax on inbound FDI reduces T for outbound FDI. This encourages capital outflows in excess of those prescribed by Musgrave (1969) and dampens the aggressive tax competition under credits found above. This also results in the non-equivalence of relief methods. When countries are identical, all Nash equilibria involve either at least one country using deductions (since this cuts outbound FDI free from domestic taxes) or credits by both. Under deductions, FDI is inefficient, however in the credit-credit equilibrium, since identical countries choose identical taxes, FDI is efficient. If deductions are proscribed, this is the unique equilibrium. Thus, even if all a treaty does is ban deductions, efficient FDI results without the need to coordinate taxes. When countries are asymmetric, the equilibrium under the treaty is not efficient because countries choose different tax rates. However, similar to Janeba (1995), if the treaty combines the use of credits or exemptions with harmonization, full efficiency results. In addition, there again exists a range of mutually beneficial harmonized taxes with the net home country preferring low taxes and the net host preferring high taxes. ${ }^{15}$

While this suggests that treaties simply require tax harmonization and elimination of deductions to reach efficiency, two papers by Chisik and Davies (forthcoming, 2003) find limits to treaty improvements due to the above-mentioned differences in preferred harmonized tax rates. In the first paper, we take the framework of Davies (2003) and embed it in a dynamic framework. Additionally, we assume that FDI is partially irreversible. Specifically, FDI in period $\mathrm{j}$ must be at least some fraction $\gamma$ of the previous period's investment, i.e. $Z_{j} \geq \gamma Z_{j-1}$. As before, each country taxes inbound FDI leading to inefficient investment without a treaty. Because FDI is bilateral, both countries enjoy efficiency improvements from mutual tax reductions. For the net host this is

\footnotetext{
${ }^{14}$ With discriminatory taxation, Davies (2003) finds Janeba's (1995) equivalence.

${ }^{15}$ Home is the net home country if its subsidiary in foreign is larger than foreign's subsidiary in home.
} 
tempered by the income shifting noted above. If a country deviates, it experiences a short-term gain from heavily taxing surprised inbound FDI and a loss when its outbound FDI is taxed in retribution. Incentive compatibility requires that the cost weakly exceed the gain. The likelihood this falls when governments place little value on the future, the degree of irreversibility increases, or asymmetry in FDI levels increases. Nevertheless, a mutually agreeable, self-enforcing tax reduction exists even if it is not fully efficient. This initial reduction raises the current level of FDI in both directions, increasing the punishment from a deviation since more FDI is trapped overseas. As a result, an additional reduction becomes self-enforcing. Therefore, taxes gradually fall over time matching the observed patterns of treaty renegotiations. Note that these additional self-enforcing taxes become credible because under the treaty governments have linked their tax policies, indicating a benefit of treaty formation that cannot be achieved unilaterally. There are, however, limits to how low tax barriers can fall. As before, tax reductions shift income from the net host to the net home. This implies that the net host may eventually find additional reductions welfare reducing. Thus, FDI asymmetries can place limits on treaty efficiency.

In Chisik and Davies (2003), we address this income shifting effect in a model of tax treaty bargaining. Using a one-period model, we derive a range of mutually beneficial, harmonized tax rates. We then use the generalized Nash bargaining solution to solve for the equilibrium tax from this range. Again, we find that the equilibrium tax is increasing in FDI asymmetries. We verify this result using 1992 data for U.S. treaty partners and for treaty partners within the OECD. Furthermore, we find FDI asymmetries also significantly reduce the likelihood of a treaty even existing. This suggests that income shifting may make treaties between developed and developing countries difficult to achieve since in those cases FDI is the most unbalanced. Indeed, income shifting led Honduras to terminate its treaty with the United States since that treaty's elimination of withholding taxes imposed large costs on the almost entirely capital importing Honduras that were not sufficiently offset by increased inbound FDI (Diamond and Diamond, 1998). 
This difference in treaty negotiations between two developed countries versus one developed and one developing country is also reflected in differences between the OECD and UN model treaties. Owens (1996) provides a detailed comparison of these two agreements and concludes that the UN treaty is favors source taxation whereas the OECD treaty emphasizes residence-based taxation. For example, the OECD treaty imposes withholding tax caps while the UN treaty does not. Since greater emphasis on source taxation reduces the revenue transfer problem, this suggests that the UN treaty may in fact be a better fit for tax treaty negotiations between rich and poor nations. Similarly, Vann (1996b) notes that as come less-developed countries have grown, particularly the Asian economies, their tax treaties have moved from the UN model towards the OECD model.

Finally, tax treaties can reduce double taxation by coordinating tax definitions and jurisdictions. Since the very question of what income is taxable by which country relies on these regulations, differences across countries can result in double taxation (Janeba, 1996). Hines (1988) finds that tax definition changes in the U.S.'s 1986 Tax Reform Act significantly affected FDI. With the increased usage of hybrid instruments (issuances that combine features of both debt and derivatives), some policy makers feel that the importance of definition coordination will increase (UN, 1998).

\section{Measuring the Effect of Tax Treaties on FDI}

From the above discussion, it is fair to say that the common assumption is that tax treaties increase FDI. Thus, one would expect a positive correlation between treaties and FDI. To test this, it is necessary to turn to the limited empirical work on FDI and tax treaties.

The first paper to deal directly with the effects of tax treaties on FDI is Blonigen and Davies (2000). ${ }^{16}$ There, we used data on inbound and outbound U.S. FDI from 1966 to 1992. We

\footnotetext{
${ }^{16}$ Hines and Willard (1992) estimate the number of tax treaties that a country has. From their results, they derive three broad themes. First, history matters as evidenced by the large number of treaties between
} 
measured FDI activity in three ways: FDI stock, FDI flows, and affiliate sales. To capture the effect of treaties, we used several approaches. In the first set of regressions, we used a simple dummy variable equal to one if there was a bilateral treaty in effect for a country pair. Here, we only found significant effects when using the FDI specification developed by Carr, Markusen, and Maskus (2001) and then only for outbound FDI. In that case, the coefficient was positive in accordance with our expectations. For the second set of regressions, we used a treaty age variable measuring how long a treaty had been in effect. There, we found positive and significant effects of treaty age on both inbound and outbound FDI for a variety of empirical specifications. Thus, our initial reaction was that treaties have a positive impact on FDI and that these effects increase over time.

One problem with this approach is that it combines the effects of old treaties that were in place long before the data begins with more recent ones. Since the old treaty partners (Australia, Canada, Europe, Japan, and New Zealand) are also the largest homes and hosts for U.S. FDI, the treaty variables may have been capturing unobserved differences between these countries and other nations. Therefore, in a more recent version of the paper (Blonigen and Davies, 2003), we use two separate dummy variables, one for old treaties and one for new treaties. This paper also extends our data through 2000. Now, we actually find a negative and significant coefficient on the pooled dummy variable. If we estimate separate effects for old and new treaties, similar to the earlier results, the old treaty dummy is positive and significant. The new treaty dummy, however, is almost always negative and frequently significant even after including country-specific fixed effects. ${ }^{17}$ When we estimate country-specific treaty coefficients, we find positive and significant

members of the same colonial empire. Second, country size is positively related to the number of treaties it has. Since large countries are large markets attractive to inbound FDI and supportive of outbound FDI, this is not surprising. Finally, government policies are important. Specifically they find that countries with low inflation and high non-treaty personal taxes have more treaties. This latter result may be indicative of the desire to reduce double taxation. Somewhat surprisingly, non-treaty corporate tax rates were insignificant although they did carry the expected positive sign. In addition, papers such as Mutti (1981) study the effect of items such as withholding taxes that are influenced by treaties, but not treaties per se.

${ }^{17}$ Time series limitations in the data preclude the inclusion of both fixed effects and the old treaty dummy. 
effects for Russia, the Czech Republic, and Mexico, especially for U.S. inbound FDI. However, we still find many negative and significant effects of treaties. Thus our more recent results indicate that the treaty formation does not have the unambiguously positive effect theory suggests.

Similar results are found in Blonigen and Davies (forthcoming), which estimates treaty effects for OECD countries. In this paper, our data covers inbound and outbound FDI stock and flow data for OECD countries from 1982 to 1992. As in our 2000 paper, we find that when pooling old and new treaties, we estimate a positive treaty coefficient. However, when we use separate old and new treaty dummies, we find that the old treaty variable is positive and significant whereas the new treaty variable is negative and insignificant. When controlling for fixed effects, we still find negative coefficients on the new treaty variable including significant results when using FDI stocks.

Using a different approach, Louie and Rousslang (2002) also find little support for the FDI promotion story. In their paper, they use 1990s income tax return data for U.S. MNEs to calculate the rate of return for foreign subsidiaries. They then test whether this rate of return varies with treaty enforcement. Unlike the Blonigen and Davies estimates, they do not separate the effects of old and new treaties and instead only consider treaties in force prior to 1987. In their regressions, they only find one significant coefficient on their treaty dummy. As above, it is negative. They attribute this finding to omitted variable bias because after including proxies for corruption and political instability, the significance of the treaty dummy fades entirely. This leads them to conclude that good governance attracts both FDI and tax treaties but that treaties have no effect on FDI.

Thus, while the empirical evidence on treaties is limited, it paints a picture that contrasts sharply with the theorists' view of treaties. 


\section{FDI-inhibiting Effects of Tax Treaties}

Although the above models suggest that treaties should increase FDI, contrary opinions exist. Owens (1996) argues that since home causes double taxation, it can reduce it just as easily unilaterally as it can in a bilateral agreement. Furthermore, since most countries offer either credits or exemptions without a treaty, there is not a large role for treaties in changing relief methods. This leaves the two facets of tax treaties that cannot be achieved unilaterally reductions in host withholding taxes and international cooperation in reducing tax evasion. I discuss these in turn below.

While one might expect withholding taxes reductions to increase FDI, the literature stemming from Hartman (1985) and Sinn (1993) suggests there may be no link between withholding taxes and investment in a mature subsidiary. ${ }^{18}$ Suppose that the MNE has made an initial equity injection (Z) into its subsidiary and that $h(K-Z, L)$ is linear in capital. After host corporate income taxes $\left(t_{c}^{*}\right)$ are paid, the firm has $\left(1-t_{c}^{*}\right) h^{s}\left(Z, L^{s}\right)$ which it can either pay out as dividends or reinvest in the subsidiary. If the MNE pays $\$ 1$ out as dividends, the return is $(1-\rho)$ where $\rho$ is the repatriation tax. If the firm is in excess limit, then $1-\rho=\frac{1-t^{s}}{1-t_{c}^{*}}$ and the firm's marginal tax rate is $\mathrm{t}^{\mathrm{s}} .{ }^{19}$ If the firm is in excess credits or operates under exemptions, then $1-\rho=1-\kappa$ where $\kappa$ is the withholding tax. If the firm reinvests that dollar, then it pays neither withholding taxes nor home taxes until repatriation. ${ }^{20}$ Upon repatriation, however, the firm will pay the same repatriation tax $\rho$. Since repatriation taxes are eventually paid either way, they cancel out in the reinvestment decision. Thus, all subsidiary income is reinvested until the after-

\footnotetext{
${ }^{18}$ For derivations of the following results, see OECD (2001) or Sinn (1993).

${ }^{19}$ Since the credit for withholding taxes equals their cost, these wash out in $\rho$.

${ }^{20}$ Under deferral, overseas profits are not subject to home taxation until they are repatriated or invested in passive assets. Examples of this common regulation include the Subpart F legislation in the U.S., the Aussensteuergesetz in Germany, and the Foreign Accrual Property Income in Canada.
} 
host corporate tax rate of return equals the constant home rate of return. ${ }^{21}$ This also implies that the size of the subsidiary when repatriation begins is independent of repatriation taxes. ${ }^{22}$

Therefore, as Sinn (1993) notes, a treaty that reduces withholding taxes will not impact the size of a mature subsidiary.

Repatriation taxes are negatively related to the initial equity injection. Weichenreider (1996), however, shows that when the MNE can also invest in the host capital market, even the initial equity injection may be independent of repatriation taxes. Empirical evidence by Grubert (1998) and Grubert and Mutti (1999) confirm this by showing that withholding taxes do not significantly affect investment levels. ${ }^{23}$ Altshuler, Newlon, and Randolph (1995) also find that permanent changes in withholding taxes do not affect repatriation patterns for U.S. firms, although transitory changes do. Thus, consistent with the estimates of Louie and Rousslang (2002), these model lead one to expect no effect from treaty formation.

This begs the question of why treaties are negotiated at all. One reason especially favored by international tax lawyers such as Dagan (2000), Radaelli (1997), and Gravelle (1998) is their role in reducing tax evasion. MNEs possess an exceptional ability to evade taxes by manipulating internal prices, a practice known as transfer pricing. ${ }^{24}$ Through transfer pricing, firms inflate costs in high-tax locations and shift profits to low-tax locations. Regulation of this practice is of primary concern for tax authorities. Note that in many cases, enforcement of anti-tax avoidance measures by one country can lead to higher tax receipts for the other government and losses for itself. In these cases, even if such a policy is desirable from a global perspective, it would not be implemented unilaterally. Since tax treaties can lead to bilateral enforcement or income transfers

\footnotetext{
${ }^{21}$ Hines and Hubbard (1990) examine 1984 U.S. tax returns and find that only $84 \%$ of U.S. subsidiaries actually paid out dividends. Altshuler and Newlon (1991) find similar results using 1986 tax returns. ${ }^{22}$ Grubert (1998) extends the Hartman-Sinn result by allowing the firm to repatriate profits through royalties and interest payments as well as dividends and finds comparable results. Altshuler and Grubert (1996) show that there exist costly "triangular" strategies which enable firms to effectively achieve repatriation without actually bringing funds home directly from the host country.

${ }^{23}$ Grubert (1998) does show that withholding taxes affect the method of repatriation.

${ }^{24}$ See Tang (1993) or Eden (1998) for discussions of transfer pricing regulation.
} 
through withholding tax manipulation, they can achieve enforcement levels great than those that are possible when countries act unilaterally.

Tax treaties address transfer pricing in three ways. First, they specify the preferred methods by which internal prices are to be calculated. Since this may run counter to the firm's preferred method, this can reduce FDI. Second, treaties address transfer pricing by setting up dispute resolution mechanisms. While these mechanisms improve the tax certainty of the firm, they can also coordinate the tax authorities, weakening the firm's position vis-à-vis the tax authorities. Finally, treaties promote the exchange of tax information.

Almost all tax treaties include articles encouraging the exchange of taxpayer information. These exchanges are intended to reduce the costs associated with tax enforcement, permit accurate implementation of treaties, and enable swift and precise enforcement of domestic tax policy. ${ }^{25}$ Information exchange can be "narrow" or "broad". The narrow view limits exchanges to those necessary to implement the treaty's provisions. The broad view, which is supported by the OECD's model treaty, encourages exchanges that help in overall tax policy enforcement. This latter approach can even include information on taxpayers who are not residents of either treaty partner. Information exchange by OECD members varies widely. Some members, such as Switzerland and Germany, are bound by national law to maintain taxpayer secrecy. ${ }^{26}$ In addition, the cost of providing information inhibits some countries (Vann, 1996a). Others, such as the United States, exchange information quite readily. The U.S. is so vigorous in its desire for information that it has even entered into a number of bilateral Tax Information Exchange Agreements which assist information exchange but lack the other provisions of tax treaties. ${ }^{27}$ Furthermore, the U.S. has made information exchange a requirement for continuing existing treaties and cancelled some treaties for their failure to do so (Eden, 1998).

\footnotetext{
${ }^{25}$ Information exchange does not oblige a country to assist in the collection of tax payments.

${ }^{26}$ See Vann (1996a) and Krabbe (1996) for details.

27 The U.S. and like-minded countries also created the Multilateral Convention on Mutual Assistance in Tax Matters (OECD, 1989) which encourages multilateral information exchange. That agreement has only been ratified by a few OECD members and therefore has limited usefulness.
} 
Since information exchange can hinder transfer pricing, this can have three effects. First, if FDI on the margin was taking place in order to transfer price, treaty formation will reduce actual investment levels. Second, even if actual investment is unaltered, information exchange can lead to profit shifting within the firm. This can alter affiliate sales, loans between related firms, royalty payments, and so forth. Third, tax evasion can take place by third-country firms engaging in treaty shopping, a practice in which instead of investing directly in the host, firms funnel investment through a third country in order to take advantage of differences among treaties (U.S. IRS, 1981). Commonly, treaty benefits are restricted if more than 50\% of a corporation's stock is held by a third country's residents (Doernberg, 1997). However, sufficient information must be exchanged in order to enforce this. Thus, increased information exchange between two countries can reduce FDI between them while increasing investment from the actual homes of treaty-shopping firms (OECD, 1994).

These effects can explain the negative treaty effects observed by Blonigen and Davies (forthcoming, 2003). Papke (2000) provides additional evidence of treaty shopping that took place through the U.S./Netherlands-Antilles treaty which, after failed attempts to plug this hole, the U.S. began dismantling in 1995. Ault and Bradford (1990) and Radaelli (1997) also find that treaty shopping has been a primary focus for recent American treaties and has prompted the U.S. to renegotiate many older treaties. While some authors such as Easson (1999) and Radaelli (1997) believe that fears over treaty shopping are primarily a U.S. phenomenon, most treaties contain some anti-abuse provision (Ward, 1995). Within the European Union, concern over "directive shopping" in which non-member firms take advantage of the elimination of withholding taxes on dividend payments within the Union has led some members to adopt anti-abuse rules. ${ }^{28}$

\footnotetext{
${ }^{28}$ See Terra and Wattel (1997) or Weber (1996) for examples.
} 


\section{The Effect of Treaty Renegotiation on FDI}

One issue not yet addressed by the empirical literature is the effect of treaty renegotiation on FDI. As observed by Chisik and Davies (forthcoming) renegotiations frequently reduce withholding taxes. This can spur additional investment from the host as well as relocations from other countries. This latter possibility is of particular relevance in the wake of James Hardie's relocation to the Netherlands after that country's treaty with the U.S. was revised to with substantially lower withholding taxes. Alternatively, if the anti-treaty shopping provisions noted by Ault and Bradford (1990) or Radaelli (1997) are the primary reason for renegotiations, then revisions may decrease FDI.

To contrast these opposing possibilities, I estimate the effect of U.S. treaty renegotiations on FDI activity from 1966 to 2000. This is the same panel data set used by Blonigen and Davies (2003). For my empirical specification, I use the Carr, Markusen, and Maskus (2001) framework as modified by Blonigen, Davies, and Head (2003). In this specification, FDI from country $\mathrm{j}$ to country $\mathrm{i}$ is given by:

$$
F D I_{i j}=\begin{gathered}
f\left(S U M G D P_{i j}, G D P D I F S Q_{i j}, S K D I F F_{i j}, S K D S U M G_{i j}\right. \\
\left.T_{-} C O S T_{i}, T_{-} C O S T_{j}, F_{-} \operatorname{COST}_{j}, \operatorname{HTSKD}_{i j}, D I S T_{i j}\right)
\end{gathered} .
$$

While I refer the reader to either of the aforementioned articles for details behind (8), the variables are defined as follows. The first term, SUMGDP, is the sum of the two countries' real GDPs. GDPDIFSQ is the squared difference between the countries' real GDP. The third term, SKDIFF, is the absolute value of the skill difference between the parent and host country. The fourth term interacts SKDIFF with SUMGDP. T_COST is the trade cost of either the home or host country. F_COST is the cost of investing in the host. HTSKD interacts host trade costs with the squared skill difference. Finally DIST is the distance between countries. Following Blonigen and Davies (2003) and Markusen and Maskus (2001), I run separate regressions for U.S. inbound and outbound FDI. 
In addition, I include several treaty variables depending on the specification. First, TREATY is a dummy variable equal to one if a treaty is in effect for a country pair in a given year. ${ }^{29}$ Second, REVISION is a dummy variable equal to one in the year a treaty's revision takes effect. Table 1 lists U.S. treaty renegotiations and the year the revision took effect. Since firms may be slow to react, in some specifications I use a dummy variable REVISION2 which is equal to one both in the year a renegotiation took effect and for two years after. ${ }^{30}$ To test whether the impact of a renegotiation depends on the size of the treaty partner, I also create a variable GDPREV that interacts the non-U.S. partner's real GDP with REVISION. Finally, to examine whether a renegotiation affects other countries, I use ANY which corresponds to REVISION but is equal to one in a year in which any renegotiation took effect. ${ }^{31}$

Following previous studies, I use two measures of FDI activity: real affiliate sales and real FDI stock. ${ }^{32}$ While the two are highly correlated, they capture somewhat different things. ${ }^{33}$ FDI stock captures the cumulative effect of past changes and expectations about future opportunities whereas sales are a reflection of the MNE's current activity. Second, FDI stock is an input and thus may not be as easily comparable across firms or countries as sales are. Third, if a revision affects transfer pricing, this can cause changes in where firms attribute sales and profits even if it does not alter investment levels. A final advantage of the stock data is that it goes back as far as 1966 whereas sales only date back to 1983. Both measures were collected from the U.S.

\footnotetext{
${ }^{29}$ Endogeneity is a natural concern since renegotiations might be driven by lobbying from large, powerful MNEs. This should bias my treaty coefficient upwards. However, since I can reject the hypothesis that revisions significantly increase FDI stock, I am not overly worried about endogeneity. Blonigen and Davies (2003) provide evidence against the endogeneity of new treaty formation.

${ }^{30}$ In unreported results, I extend this as far as five years with no qualitative change.

${ }^{31}$ Extending ANY to multiple years as with REVISION2 yields a near constant.

${ }^{32}$ In unreported results that are available on request, I also used FDI flows (the change in stocks) as my dependent variable. This yields negative coefficients for REVISION in the inbound regressions and positive coefficients for the outbound regressions with significance generally found when I restrict the sample to the OECD. The ANY variable was negative but never significant. Thus, for outbound FDI these results match those from the sales data whereas for inbound FDI the results mirror those from stocks. One possibility for this difference between inbound and outbound flows is that revisions may favor U.S. MNEs relative to treaty partners' firms. In any case, since the significance depends greatly on the cut of the data, I am unable to point to a conclusively positive effect from treaty revisions.

${ }^{33}$ The pairwise correlation is 0.92 for inbound FDI activity and 0.90 for outbound FDI.
} 
Bureau of Economic Analysis's Internet site and were converted into thousands of real 1996 U.S. dollars using the U.S. chain-type price index for gross domestic investment reported in the Economic Report of the President.$^{34}$ Data on real GDP and trade openness (equal to 100 minus T_COST) come from version 6.1 of the Penn-World Tables. ${ }^{35}$ Skill data come from Barro and Lee's International Data on Educational Attainment which reports the average years of schooling for those over age $25 .{ }^{36}$ These data are measured every five years and I used linear interpolation for in-between years. Distance is measured in miles between capital cities as reported by the Bali Online Corporation. ${ }^{37}$ Investment costs come from the composite score compiled by Business Environment Risk Intelligence, S.A. and are ranked from 0 to 100. Finally, information on U.S. treaties and revisions was collected from the Worldwide Tax Treaties database at Tax.com. ${ }^{38}$

The results from my regressions appear in Tables 2 through 5. On the whole, my control variables have coefficients similar to Blonigen, Davies, and Head (2003). In the interest of space, I forgo additional discussion of these. I include country-specific fixed effects in all specifications which precludes estimation of separate old and new treaty effects. Tables 2 and 3 report estimates using FDI stock for as many countries as possible. As in Blonigen and Davies (2003), I find that the combined TREATY dummy carries a negative and significant coefficient. Revisions, however, are generally insignificant. As Table 2 reports, neither the REVISION nor the REVISION2 variable is significant although both have negative coefficients. In Table 3, Columns 1 and 2 add the ANY variable to the initial regressions. Again no significant effect is found, although both revision variables again have negative coefficients. Columns 3 and 4 replace ANY

\footnotetext{
${ }^{34}$ FDI is classified as arising from the country in which the parent resides. Thus, if an Australian firm invests in the U.K. to take advantage of the U.K.'s treaty with the US, the BEA classifies this as inbound FDI from the U.K.. Although the BEA does have data that attributes FDI according to the residence of the ultimate beneficial owner, these data are far more limited across countries and time. Also, they do not allow me to test whether a revision of the U.S./U.K. treaty that counters treaty shopping causes FDI to then flow directly from Australia instead of through the U.K. Therefore I do not use this alternative measure.

${ }^{35}$ Summers and Heston (1991) describe this data which is available at http://pwt.econ.upenn.edu.

${ }^{36}$ These data are available at http://www.worldbank.org/research/growth/ddbarle2.htm. Details are given by Barro and Lee (1996).

${ }^{37}$ These data were found at http://www.indo.com.

${ }^{38}$ Instead of the effective year, I could have used the year the renegotiated treaty was signed. This yields similar results.
} 
with GDPREV. For inbound FDI, I again find negative but insignificant effects of treaty renegotiations. Only in outbound results of Column 4 do renegotiations have a significant effect. There, REVISION has a significantly negative coefficient suggesting that a revision lowers U.S. FDI in the partner country. While this is tempered somewhat by the significant coefficient on GDPREV, that variable's small estimated coefficient (.0000063) is not enough to overturn the overall negative effect of a revision. Unreported results using affiliate sales find comparable effects. Thus, initial results find no strong positive effect of renegotiations on FDI.

One potential difficulty with the above results is that all revisions happen with developed countries. In particular, since a revision with a developed country is most likely to draw FDI from another developed country (as in the James Hardie case), it is useful to restrict the sample to OECD members. As Table 4 shows, results using FDI stock from OECD countries is broadly consistent with the above estimates, that is neither treaties nor renegotiations exhibit strong positive effects on FDI. Unlike the broader sample, I now find an impact of a revision on other countries. Specifically, I find a negative coefficient on ANY for U.S. inbound data. This regression is also the only one that yields a positive (if insignificant) coefficient on REVISION. This provides weak evidence that the relocation issue may be present within the OECD but that this effect is small.

In Table 5, I report estimates from the OECD sample when I use affiliate sales as my measure of FDI. Although sales and stocks are highly correlated, the REVISION coefficients are very different. When using sales, the REVISION variable is positive and significant for inbound and outbound FDI. At the same time, the ANY variable becomes positive if insignificant. I can easily conceive of four reasons for this difference. First, recall that the stock data covers nearly twice as many years as the sales data. If I restrict the stock regressions to the same observations as the sales regression, I find positive REVISION coefficients although they are insignificant. 
Thus, time period is partially to blame. ${ }^{39}$ Second, it may be that FDI stocks take longer to react to revisions than sales do. To test this, I tested for revision effects up to five years after the revision became effective. Despite this, I was unable to find significant coefficients when using stocks. Third, endogeneity could be a problem if large sales induce renegotiations (although I would expect a similar problem with the stock data). Finally, it may be that MNEs are adjusting their bookkeeping if not actual investment. Since revisions fight transfer pricing, firms in these countries may simply be forced to report more income in the partner country after the treaty. Alternatively, firms may be shifting even more income to these nations to take advantage of the new and attractive withholding taxes. In any case, I leave the reason for this difference open for future research and instead conclude that in order to find the treaty promotion results politicians promise and theorists model it is necessary to look under rather specific rocks.

\section{Conclusion}

While relatively little has been written on tax treaties and FDI, the existing work raises many interesting questions. In particular, the search for convincing FDI-promoting effects of treaties is a topic of interest both to researchers and policy makers. If these effects are not found, it calls into question the typical rationale assigned to treaties. While my overview is necessarily limited in scope and length, I hope that it nevertheless serves as a useful entry point for future research.

\footnotetext{
${ }^{39}$ In unreported results with quadratic time trends, this difference in significance remains.
} 
Table 1: U.S. Treaty Revisions

\begin{tabular}{|l|l|l|l|}
\hline Australia (1983) & Austria (1998) & Barbados (1984) & Belgium (1971) \\
\hline Canada (1941, 1984) & Denmark (2000) & Finland (1972) & $\begin{array}{l}\text { France (1945, 1968, } \\
1996)\end{array}$ \\
\hline Germany (1990) & Ireland (1998) & Italy (1986) & Japan (1973) \\
\hline Luxembourg (2001) & Netherlands (1994) & New Zealand (1984) & Sweden (1997) \\
\hline Switzerland (1998) & $\begin{array}{l}\text { Trinidad and Tobago } \\
(1970)\end{array}$ & $\begin{array}{l}\text { United Kingdom } \\
(1975)\end{array}$ & \\
\hline
\end{tabular}

NOTES: Year renegotiation took effect in parentheses. 
Table 2: Revision Effects on U.S. FDI Stock

\begin{tabular}{|c|c|c|c|c|}
\hline & Inbound & Outbound & Inbound & Outbound \\
\hline SUMGDP $_{i j}$ & $\begin{array}{c}10.0 * * * \\
(4.06)\end{array}$ & $\begin{array}{l}3.4^{* *} \\
(2.05)\end{array}$ & $\begin{array}{l}9.9 * * * \\
(4.05)\end{array}$ & $\begin{array}{l}3.5^{* *} \\
(2.06)\end{array}$ \\
\hline GDPDIFSQ $_{\mathrm{ij}}$ & $\begin{array}{c}-0.0 * * * \\
(4.30)\end{array}$ & $\begin{array}{c}-0.0 * * * \\
(3.06)\end{array}$ & $\begin{array}{c}-0.0 * * * \\
(4.33)\end{array}$ & $\begin{array}{c}-0.0 * * * \\
(3.01)\end{array}$ \\
\hline SKDIFF $_{i j}$ & $\begin{array}{c}3,959.6 \\
(1.31)\end{array}$ & $\begin{array}{c}7,336.5 * * * \\
(5.71)\end{array}$ & $\begin{array}{c}3,746.2 \\
(1.22)\end{array}$ & $\begin{array}{c}7,339.0 * * * \\
(5.63)\end{array}$ \\
\hline SKDSUMG $_{\mathrm{ij}}$ & $\begin{array}{l}-0.1 \\
(0.72)\end{array}$ & $\begin{array}{c}-0.6^{* * *} \\
(5.04)\end{array}$ & $\begin{array}{l}-0.1 \\
(0.76)\end{array}$ & $\begin{array}{c}-0.6^{* * *} \\
(4.95)\end{array}$ \\
\hline F_COST $_{i}$ & $\begin{array}{l}354.6^{*} \\
(1.90)\end{array}$ & $\begin{array}{c}-156.5^{* *} \\
(2.31)\end{array}$ & $\begin{array}{l}345.1^{*} \\
(1.84)\end{array}$ & $\begin{array}{c}-157.9 * * \\
(2.31)\end{array}$ \\
\hline$T_{-} \operatorname{COST}_{i}$ & $\begin{array}{c}-1,961.7 * * * \\
(4.19)\end{array}$ & $\begin{array}{c}-102.2^{* * *} \\
(5.01)\end{array}$ & $\begin{array}{c}-1,968.5^{* * *} \\
(4.23)\end{array}$ & $\begin{array}{c}-102.3 * * * \\
(4.93)\end{array}$ \\
\hline HTSKD $_{\mathrm{ij}}$ & $\begin{array}{l}9.9 * * * \\
(4.61)\end{array}$ & $\begin{array}{l}2.1 * * * \\
(5.34)\end{array}$ & $\begin{array}{l}9.8 * * * \\
(4.45)\end{array}$ & $\begin{array}{l}2.1 * * * \\
(5.32)\end{array}$ \\
\hline$T_{-} \operatorname{COST}_{j}$ & $\begin{array}{c}44.1 * * * \\
(3.88)\end{array}$ & $\begin{array}{c}-2,381.3 * * * \\
(4.26)\end{array}$ & $\begin{array}{c}44.5^{* * *} \\
(3.95)\end{array}$ & $\begin{array}{c}-2,362.8^{* * * *} \\
(4.21)\end{array}$ \\
\hline TREATY $_{\mathrm{ij}}$ & $\begin{array}{c}-7,567.6^{* * *} \\
(6.12)\end{array}$ & $\begin{array}{c}-4,273.6^{* * *} \\
(4.29)\end{array}$ & $\begin{array}{c}-7,563.4 * * * \\
(6.10)\end{array}$ & $\begin{array}{c}-4,269.7 * * * \\
(4.27)\end{array}$ \\
\hline REVISION $_{\mathrm{ij}}$ & $\begin{array}{c}-1,150.4 \\
(0.48)\end{array}$ & $\begin{array}{c}-2,779.2 \\
(1.38)\end{array}$ & & \\
\hline REVISION $2_{\mathrm{ij}}$ & & & $\begin{array}{c}1,635.3 \\
(0.74)\end{array}$ & $\begin{array}{l}-757.9 \\
(0.51)\end{array}$ \\
\hline Constant & $\begin{array}{c}101,408.9 * * \\
(2.00)\end{array}$ & $\begin{array}{c}187,867.4^{* * *} \\
(3.27)\end{array}$ & $\begin{array}{c}102,356.6^{* *} \\
(2.03)\end{array}$ & $\begin{array}{c}186,053.7^{* * * *} \\
(3.21)\end{array}$ \\
\hline Observations & 1490 & 892 & 1490 & 892 \\
\hline R-squared & 0.80 & 0.80 & 0.80 & .80 \\
\hline
\end{tabular}

NOTES: Robust t-statistics are in parentheses, with ***,**, and * denoting statistical significance (two-tailed test) at the 1, 5, and 10 percent levels, respectively. All regressions also include country-specific dummy variables. 
Table 3: Revision Effects on U.S. FDI Stock

\begin{tabular}{|c|c|c|c|c|}
\hline & Inbound & Outbound & Inbound & Outbound \\
\hline SUMGDP $_{i j}$ & $\begin{array}{l}9.9 * * * \\
(4.05)\end{array}$ & $\begin{array}{l}3.4^{* *} \\
(2.03)\end{array}$ & $\begin{array}{c}10.0 * * * \\
(4.06)\end{array}$ & $\begin{array}{l}3.4^{* * *} \\
(2.02)\end{array}$ \\
\hline GDPDIFSQ $_{\mathrm{ij}}$ & $\begin{array}{c}-0.0 * * * \\
(4.29)\end{array}$ & $\begin{array}{c}-0.0 * * * \\
(3.09)\end{array}$ & $\begin{array}{c}-0.0 * * * \\
(4.30)\end{array}$ & $\begin{array}{c}-0.0 * * * \\
(3.06)\end{array}$ \\
\hline SKDIFF $_{i j}$ & $\begin{array}{c}4,072.5 \\
(1.35)\end{array}$ & $\begin{array}{c}7,319.1 * * * \\
(5.69)\end{array}$ & $\begin{array}{c}3,957.0 \\
(1.31)\end{array}$ & $\begin{array}{c}7,373.5^{* * * *} \\
(5.72)\end{array}$ \\
\hline SKDSUMG $_{\mathrm{ij}}$ & $\begin{array}{l}-0.1 \\
(0.67)\end{array}$ & $\begin{array}{c}-0.6^{* * *} \\
(5.03)\end{array}$ & $\begin{array}{l}-0.1 \\
(0.72)\end{array}$ & $\begin{array}{c}-0.6^{* * * *} \\
(5.05)\end{array}$ \\
\hline F_COST $_{i}$ & $\begin{array}{c}394.1 * * \\
(2.04)\end{array}$ & $\begin{array}{c}-157.4 * * \\
(2.31)\end{array}$ & $\begin{array}{l}353.3^{*} \\
(1.89)\end{array}$ & $\begin{array}{c}-160.1^{* *} \\
(2.36)\end{array}$ \\
\hline$T_{-} \operatorname{COST}_{i}$ & $\begin{array}{c}-2,034.3 * * * \\
(4.21)\end{array}$ & $\begin{array}{c}-102.0 * * * \\
(4.99)\end{array}$ & $\begin{array}{c}-1,956.7^{* * *} \\
(4.18)\end{array}$ & $\begin{array}{c}-102.8 * * * \\
(4.99)\end{array}$ \\
\hline HTSKD $_{\mathrm{ij}}$ & $\begin{array}{c}10.0 * * * \\
(4.62)\end{array}$ & $\begin{array}{l}2.1 * * * \\
(5.31)\end{array}$ & $\begin{array}{l}9.9 * * * \\
(4.61)\end{array}$ & $\begin{array}{l}2.1 * * * \\
(5.33)\end{array}$ \\
\hline$T_{-} \operatorname{COST}_{j}$ & $\begin{array}{c}44.3 * * * \\
(3.89)\end{array}$ & $\begin{array}{c}-2,410.2 * * * \\
(4.36)\end{array}$ & $\begin{array}{c}44.1 * * * \\
(3.88)\end{array}$ & $\begin{array}{c}-2,406.1 * * * \\
(4.31)\end{array}$ \\
\hline TREATY $_{\mathrm{ij}}$ & $\begin{array}{c}-7,584.6^{* * *} \\
(6.10)\end{array}$ & $\begin{array}{c}-4,257.2 * * * \\
(4.27)\end{array}$ & $\begin{array}{c}-7,565.9^{* * *} \\
(6.11)\end{array}$ & $\begin{array}{c}-4,280.4^{* * * *} \\
(4.29)\end{array}$ \\
\hline REVISION $_{\mathrm{ij}}$ & $\begin{array}{l}-941.5 \\
(0.39)\end{array}$ & $\begin{array}{c}-2,650.8 \\
(1.29)\end{array}$ & $\begin{array}{l}-351.1 \\
(0.12)\end{array}$ & $\begin{array}{c}-5,766.5^{* *} \\
(2.05)\end{array}$ \\
\hline ANY & $\begin{array}{l}-493.4 \\
(1.00)\end{array}$ & $\begin{array}{l}-268.6 \\
(0.38)\end{array}$ & & \\
\hline GDP*REV & & & $\begin{array}{c}-0.0 \\
(0.36)\end{array}$ & $\begin{array}{l}0.0 * * \\
(2.05)\end{array}$ \\
\hline Constant & $\begin{array}{c}105,874.6^{* *} \\
(2.07)\end{array}$ & $\begin{array}{c}190,891.1^{* * * *} \\
(3.35)\end{array}$ & $\begin{array}{c}101,006.3^{* *} \\
(1.99)\end{array}$ & $\begin{array}{c}190,445.9^{* * * *} \\
(3.32)\end{array}$ \\
\hline Observations & 1490 & 892 & 1490 & 892 \\
\hline R-squared & 0.80 & 0.80 & 0.80 & 0.80 \\
\hline
\end{tabular}

NOTES: Robust t-statistics are in parentheses, with $* * *, * *$, and $*$ denoting statistical significance (two-tailed test) at the 1, 5, and 10 percent levels, respectively. All regressions also include country-specific dummy variables. 
Table 4: Revision Effects on U.S. FDI Stock - OECD only

\begin{tabular}{|c|c|c|c|c|}
\hline & Inbound & Outbound & Inbound & Outbound \\
\hline $\mathbf{S U M G D P}_{\mathrm{ij}}$ & $\begin{array}{l}35.1 * * * \\
(12.46)\end{array}$ & $\begin{array}{c}14.6 * * * \\
(4.53)\end{array}$ & $\begin{array}{l}35.0 * * * \\
(12.55)\end{array}$ & $\begin{array}{c}14.5 * * * \\
(4.54)\end{array}$ \\
\hline GDPDIFSQ $_{\mathrm{ij}}$ & $\begin{array}{l}-0.0 * * * \\
(12.67)\end{array}$ & $\begin{array}{c}-0.0 * * * \\
(5.52)\end{array}$ & $\begin{array}{l}-0.0 * * * \\
(12.81)\end{array}$ & $\begin{array}{c}-0.0 * * * \\
(5.57)\end{array}$ \\
\hline SKDIFF $_{i j}$ & $\begin{array}{c}-1,534.4 \\
(0.36)\end{array}$ & $\begin{array}{c}9,862.3^{* * *} \\
(2.85)\end{array}$ & $\begin{array}{c}-1,579.6 \\
(0.37)\end{array}$ & $\begin{array}{c}9,835.3 * * * \\
(2.84)\end{array}$ \\
\hline SKDSUMG $_{\mathrm{ij}}$ & $\begin{array}{c}0.0 \\
(0.10)\end{array}$ & $\begin{array}{c}-0.6 \\
(1.45)\end{array}$ & $\begin{array}{c}0.0 \\
(0.10)\end{array}$ & $\begin{array}{c}-0.6 \\
(1.45)\end{array}$ \\
\hline F_COST $_{i}$ & $\begin{array}{c}1,381.3 * * * \\
(3.88)\end{array}$ & $\begin{array}{l}-75.6 \\
(0.64)\end{array}$ & $\begin{array}{c}1,553.2 * * * \\
(4.31)\end{array}$ & $\begin{array}{l}-73.5 \\
(0.63)\end{array}$ \\
\hline$T_{-} \operatorname{COST}_{i}$ & $\begin{array}{c}-2,358.7 * * * \\
(3.08)\end{array}$ & $\begin{array}{c}-204.5^{* * *} \\
(3.12)\end{array}$ & $\begin{array}{c}-2,624.1^{* * * *} \\
(3.37)\end{array}$ & $\begin{array}{c}-205.0 * * * \\
(3.12)\end{array}$ \\
\hline HTSKD $_{\mathrm{ij}}$ & $\begin{array}{c}14.4 * * * \\
(3.69)\end{array}$ & $\begin{array}{c}3.3 \\
(1.08)\end{array}$ & $\begin{array}{c}14.2 * * * \\
(3.65)\end{array}$ & $\begin{array}{c}3.3 \\
(1.07)\end{array}$ \\
\hline $\mathbf{T}_{-} \operatorname{COST}_{\mathbf{j}}$ & $\begin{array}{c}33.7 \\
(0.60)\end{array}$ & $\begin{array}{c}-2,312.8 * * \\
(2.46)\end{array}$ & $\begin{array}{c}35.0 \\
(0.63)\end{array}$ & $\begin{array}{c}-2,379.4^{* *} \\
(2.58)\end{array}$ \\
\hline TREATY $_{\mathrm{ij}}$ & $\begin{array}{c}-2,955.2 \\
(1.64)\end{array}$ & $\begin{array}{c}1,417.1 \\
(1.24)\end{array}$ & $\begin{array}{c}-3,154.6^{*} \\
(1.73)\end{array}$ & $\begin{array}{c}1,385.1 \\
(1.21)\end{array}$ \\
\hline $\begin{array}{l}\text { REVISION }_{\mathrm{ij}} \\
\text { ANY }\end{array}$ & $\begin{array}{c}-6.3 \\
(0.00)\end{array}$ & $\begin{array}{c}-2,434.0 \\
(1.19)\end{array}$ & $\begin{array}{c}950.4 \\
(0.37) \\
-2,195.8^{* *} \\
(2.41)\end{array}$ & $\begin{array}{c}-2,159.9 \\
(1.00) \\
-594.4 \\
(0.51)\end{array}$ \\
\hline Constant & $\begin{array}{c}-60,868.0 \\
(0.69)\end{array}$ & $\begin{array}{c}134,703.4 \\
(1.40)\end{array}$ & $\begin{array}{c}-47,966.9 \\
(0.54)\end{array}$ & $\begin{array}{c}141,444.5 \\
(1.50)\end{array}$ \\
\hline Observations & 553 & 494 & 553 & 494 \\
\hline R-squared & 0.88 & 0.81 & 0.88 & 0.81 \\
\hline
\end{tabular}

NOTES: Robust t-statistics are in parentheses, with ***,**, and * denoting statistical significance (two-tailed test) at the 1, 5, and 10 percent levels, respectively. All regressions also include country-specific dummy variables. 
Table 5: Revision Effects on U.S. Affiliate Sales - OECD only

\begin{tabular}{|c|c|c|c|c|}
\hline & Inbound & Outbound & Inbound & Outbound \\
\hline \multirow[t]{2}{*}{ SUMGDP $_{\mathrm{ij}}$} & $1.0 * * *$ & $0.4 * * *$ & $1.1^{* * *}$ & $0.5 * * *$ \\
\hline & (14.49) & $(7.45)$ & (14.39) & $(7.43)$ \\
\hline \multirow[t]{2}{*}{ GDPDIFSQ $_{\mathrm{ij}}$} & $-0.0 * * *$ & $-0.0 * * *$ & $-0.0 * * *$ & $-0.0 * * *$ \\
\hline & (14.59) & $(7.80)$ & (14.56) & $(7.78)$ \\
\hline \multirow[t]{2}{*}{ SKDIFF $_{i j}$} & -12.2 & $254.3 * * *$ & -9.9 & $246.4 * * *$ \\
\hline & $(0.14)$ & (3.67) & $(0.12)$ & $(3.54)$ \\
\hline \multirow[t]{2}{*}{ SKDSUMG $_{\mathrm{ij}}$} & -0.0 & $-0.0 * *$ & -0.0 & $-0.0 * *$ \\
\hline & $(0.42)$ & $(2.38)$ & $(0.40)$ & $(2.27)$ \\
\hline \multirow[t]{2}{*}{ F_COST $_{i}$} & $27.0 * * *$ & -1.1 & $26.2 * * *$ & -1.1 \\
\hline & $(3.95)$ & $(0.46)$ & $(3.86)$ & $(0.48)$ \\
\hline \multirow[t]{2}{*}{$\mathbf{T}_{-} \mathrm{COST}_{\mathrm{i}}$} & -25.5 & $-3.7 * * *$ & -22.2 & $-3.7 * * *$ \\
\hline & $(1.50)$ & $(2.84)$ & $(1.28)$ & $(2.89)$ \\
\hline \multirow[t]{2}{*}{ HTSKD $_{\mathrm{ij}}$} & $0.3 * * *$ & -0.0 & $0.3 * * *$ & -0.0 \\
\hline & $(3.81)$ & $(0.24)$ & $(3.82)$ & $(0.16)$ \\
\hline \multirow[t]{2}{*}{$T_{-} \operatorname{COST}_{j}$} & 1.9 & $-68.7 * * *$ & 1.9 & $-62.1 * * *$ \\
\hline & (1.39) & $(3.66)$ & $(1.37)$ & $(3.39)$ \\
\hline \multirow[t]{2}{*}{ TREATY $_{i j}$} & -3.3 & 41.0 & -4.0 & 40.4 \\
\hline & $(0.09)$ & $(1.27)$ & $(0.10)$ & $(1.26)$ \\
\hline \multirow[t]{2}{*}{ REVISION $_{\mathrm{ij}}$} & $96.0 * *$ & $55.1 * *$ & $91.9 * *$ & $49.4 *$ \\
\hline & $(2.17)$ & $(2.01)$ & $(2.05)$ & (1.76) \\
\hline \multirow[t]{2}{*}{ ANY } & & & 11.3 & 15.2 \\
\hline & & & $(0.90)$ & $(1.14)$ \\
\hline \multirow[t]{2}{*}{ Constant } & $-4,385.2 * *$ & $4,400.3 * *$ & $-4,654.4 * *$ & $3,734.2 * *$ \\
\hline & $(2.22)$ & $(2.35)$ & $(2.31)$ & $(2.02)$ \\
\hline Observations & 369 & 366 & 369 & 366 \\
\hline R-squared & 0.98 & 0.97 & 0.98 & 0.97 \\
\hline
\end{tabular}

NOTES: Robust t-statistics are in parentheses, with ***,**, and * denoting statistical significance (two-tailed test) at the 1, 5, and 10 percent levels, respectively. All regressions also include country-specific dummy variables. 


\section{References}

Altshuler, R. and H. Grubert (1996), Balance sheets, multinational financial policy and the cost of capital at home and abroad, Working Paper No. 5810, National Bureau of Economic Research, New York.

Altshuler, R. and T. S. Newlon (1991), The effects of U.S. tax policy on the income repatriation patterns of U.S. multinational Corporations, Working Paper No. 3925, National Bureau of Economic Research, New York.

Altshuler, R., T. S. Newlon and W. Randolph (1995), Do repatriation taxes matter? Evidence from the tax returns of U.S. multinationals, in eds. M. Feldstein, J. Hines, Jr. and R. G. Hubbard, Effects of Taxation on Multinational Corporations, Chicago: University of Chicago Press, pp. 253-272.

Ault, H. and D. Bradford (1990), Taxing international income: An analysis of the U.S. system and its economic premises, in eds. A. Razin and J. and Slemrod, Taxation in the Global Economy, Chicago: University of Chicago Press, pp. 11-46.

Baker, P. (1994), Double Taxation Conventions and International Tax Law: A Manual on the OECD Model Tax Convention on Income and on Capital of 1992, 2nd Edition, London: Sweet \& Maxwell.

Barro, R. and J.W. Lee (1996), International measures of schooling years and schooling quality, American Economic Review Papers and Proceedings, 86, pp. 218-223.

Blonigen, B. and R. Davies (2000), The effects of bilateral tax treaties on U.S. FDI activity, Working Paper No. 7929, National Bureau of Economic Research, New York.

Blonigen, B. and R. Davies (2003), The effects of bilateral tax treaties on U.S. FDI activity, Mimeo.

Blonigen, B. and R. Davies (forthcoming), Do bilateral tax treaties promote foreign direct investment? Handbook of International Trade and Law (Blackwell Publishers).

Blonigen, B., R. Davies, and K. Head (2003), Estimating the knowledge-capital model of the multinational enterprise: Comment, American Economic Review, 93, pp. 1-15.

Bond, E. and L. Samuelson (1989), Strategic behaviour and the rules for international taxation of capital, Economic Journal, 99, pp. 1099-1111.

Bradford, D. (1984), Blueprints for Basic Tax Reform, 2nd Edition, Arlington: U.S. Treasury Department.

Carr, D., J. Markusen, and K. Maskus (2001), Testing the knowledge capital model of the multinational enterprise, American Economic Review, 91, pp. 693-708.

Caves, R. (1993), Multinational Enterprise and Economic Analysis, 2nd Edition, New York: Cambridge Press. 
Chisik, R. and R. Davies (2003), Asymmetric FDI and tax treaty bargaining: theory and evidence, Mimeo.

Chisik, R. and R. Davies (forthcoming), Gradualism in tax treaties with irreversible foreign direct investment, International Economic Review.

Dagan, T. (2000), The tax treaties myth, New York University Journal of International Law and Politics, Summer, pp. 939-996.

Davies, R., (2003), The OECD model tax treaty: tax competition and two-way capital flows, International Economic Review, 44, pp. 725-753.

Davies, R. and T. Gresik, (2003), Tax competition and foreign debt, International Tax and Public Finance, 10, pp. 127-145.

Diamond, W. and D. Diamond (1998), International Tax Treaties of All Nations, Dobbs Ferry: Ocean Publications.

Doernberg, R. (1997), International Taxation in a Nutshell, 3rd Edition, St. Paul: West Publishing Co., St. Paul, Minnesota.

Drabek, Z. and W. Payne (2002), The impact of transparency on foreign direct investment, Journal of Economic Integration, 17, pp. 777-810.

Easson, A. (1999), Taxation of Foreign Direct Investment: An Introduction, The Hague: Kluwer Law International.

Eden, L. (1998), Taxing Multinationals: Transfer Pricing and Corporate Income Taxation in North America, Toronto: University of Toronto Press.

Feldstein, M. and D. Hartman (1979), The optimal taxation of foreign source investment income, Quarterly Journal of Economics, 93, pp. 613-629.

Giannini, S. and C. Maggiulli (2002), Effective tax rates in the EU Commission study on company taxation: methodological aspects, main results, and policy implications, Ifo Studien, 48, pp. 633-53.

Gordon, R. (1992), Can capital income taxes survive in open economies? The Journal of Finance, 67 , pp. 1159-80.

Gravelle, P. (1988), Tax treaties: Concepts, objectives and types, International Bureau of Fiscal Documentation, Bulletin 522, pp. 522-26.

Gresik, T. (2001), The taxing task of taxing transnationals, Journal of Economic Literature, 39, pp. 800-838.

Grubert, H. (1998), Taxes and the division of foreign operating income among royalties, interest, dividends, and retained earnings, Journal of Public Economics, 68, pp. 269-290.

Grubert, H. and J. Mutti (1999), Dividend exemption versus the current system for taxing foreign business income, Mimeo. 
Hamada, K. (1966), Strategic aspects of taxation on foreign investment income, Quarterly Journal of Economics, 80, pp. 361-75.

Hartman, D. (1985), Tax policy and foreign direct investment, Journal of Public Economics, 26, pp. 107-121.

Hines, J. R. Jr. (1988), Taxation and U.S. multinational investment, in ed. L. Summers, Tax Policy and the Economy, Cambridge: MIT Press, pp. 33-61.

Hines, J. R. Jr. and R. G. Hubbard (1990), Coming home to America: Dividend repatriations by U.S. multinationals, in eds. A. Razin and J. Slemrod, Taxation in the Global Economy, Chicago: University Chicago Press, pp. 161-200.

Hines, J. R. Jr. and K. Willard (1992), Trick or treaty? Bargains and surprises in international tax agreements, Mimeo.

Hufbauer, G. (1992), U. S. Taxation of International Income: Blueprint for Reform, Washington, D.C.: Institute for International Economics.

Janeba, E. (1995), Corporate income tax competition, double taxation treaties, and foreign direct investment, Journal of Public Economics, 56, pp. 311-325.

Janeba, E. (1996), Foreign direct investment under oligopoly: profit shifting or profit capturing? Journal of Public Economics, 60, pp. 423-445.

Jones, B. (1996), International tax developments and double taxation agreements in Australia, in ed. R. Vann, Tax Treaties: Linkages Between OECD Member Countries and Dynamic NonMember-Economies, Paris: OECD Committee on Fiscal Affairs, pp. 19-26.

Krabbe, H. (1996), The experience of Germany, in ed. R. Vann, Tax Treaties: Linkages Between OECD Member Countries and Dynamic Non-Member-Economies, Paris: OECD Committee on Fiscal Affairs, pp. 181-186.

Louie, H. and D. Rousslang (2002), Host-Country governance, tax treaties, and American direct investment abroad, Mimeo.

Markusen, J. (2002), Multinational Firms and the Theory of International Trade, Cambridge: The MIT Press.

Markusen, J. and K. Maskus (2001), Multinational firms: reconciling theory and evidence, in eds. M. Blomstrom and L. Goldberg, Topics in Empirical International Economics: A Festschrift in Honor of Robert E. Lipsey. Chicago: University of Chicago Press for National Bureau of Economic Research.

Mintz, J. and H. Tulkens, (1986), Optimality properties of alternative systems of taxation of foreign capital income, Journal of Public Economics, 60, pp. 373-399.

Musgrave, P. (1969), United States Taxation of Foreign Investment Income: Issues and Arguments, Ph.D. Dissertation, Harvard Law School. 
Mutti, J. (1981), Tax incentives and repatriation decisions of U.S. multinational corporations, National Tax Journal, 34, pp. 241-48.

Organization for Economic Cooperation and Development (1989), Explanatory report on the convention on mutual administrative assistance in tax matters, Paris: OECD Committee on Fiscal Affairs.

Organization for Economic Cooperation and Development (1994), Tax Information Exchange Between OECD Member Countries: A Survey of Current Practices, Paris: OECD Committee on Fiscal Affairs.

Organization for Economic Cooperation and Development (1997), Model tax convention on income and on capital, Paris: OECD Committee on Fiscal Affairs.

Organization for Economic Cooperation and Development (2001), Corporate Tax Incentives for Foreign Direct Investment, Paris: OECD Committee on Fiscal Affairs.

Owens, J. (1996), The main differences between the OECD and the United Nations model conventions, in ed. R. Vann Tax Treaties: Linkages Between OECD Member Countries and Dynamic Non-Member-Economies, Paris: OECD Committee on Fiscal Affairs, pp. 49-56.

Papke, L. (2000), One-way treaty with the world: the U.S. withholding tax and the Netherlands Antilles, International Tax and Public Finance, 7, pp. 295-313.

Radaelli, C. (1997), The politics of corporate taxation in the European Union, London: Routledge Research in European Public Policy.

Rajan, R. and S. Marwah (1998), The effects of policy uncertainty on the choice and timing of foreign direct investment: An exploratory firm-level assessment, Journal of Economic Development, 23, pp. 37-56.

Sasseville, J. (1996), Current Issues in International Tax Policy, in ed. R. Vann, Tax Treaties: Linkages Between OECD Member Countries and Dynamic Non-Member-Economies, Paris: OECD Committee on Fiscal Affairs, pp. 9-13.

Sinn, H. (1993), Taxation and the birth of foreign subsidiaries, in eds. H Heberg and N. Long, Trade, Welfare, and Economic Policies, Essays in Honor of Murray C. Kemp, Ann Arbor: University of Michigan Press.

Slemrod, J. (1988), Effect of taxation with international capital mobility, in Uneasy compromise: Problems of a hybrid income-consumption tax, Studies of Government Finance: Second Series, Washington, D.C.: Brookings Institution, pp. 115-48.

Summers, R. and A. Heston (1991), The Penn-World Table (Mark 5): an expanded set of international comparisons, 1950 - 1988, Quarterly Journal of Economics, 106, pp. 327-368.

Tang, R. (1993), Transfer Pricing in the 1990s: Tax and Management Perspectives, Hartford: Quorum.

Terra, B. and P. Wattel (1997), European Tax Law, The Hague: Kluwer Law International. 
United Nations (1998), Taxation of derivatives and new financial instruments, International Cooperation in Tax Matters, New York: UN, pp. 52-73.

United Nations (2001), Model Double Taxation Convention between Developed and Developing Countries, New York: UN.

United States Internal Revenue Service (1981), Tax Havens and Their Use by United States Taxpayers, The Gordon Report, Washington D.C.: Special Council for International Taxation, Internal Revenue Service.

Vann, R. (1996a), Policy dialogue with dynamic non-member economies, in ed. R. Vann, Tax Treaties: Linkages Between OECD Member Countries and Dynamic Non-Member-Economies, Paris: OECD Committee on Fiscal Affairs, pp. 195-211.

Vann, R. (1996b), Tax treaty policy of dynamic non-member countries, in ed. R. Vann, Tax Treaties: Linkages Between OECD Member Countries and Dynamic Non-Member-Economies, Paris: OECD Committee on Fiscal Affairs, pp. 57-88.

Ward, D. (1995), Abuse of tax treaties, Intertax, 23, pp. 177.

Weber, D. (1996), A closer look at the general anti-abuse clause in the parent-subsidiary directive and the merger directive, EC Tax Review, 5, pp. 63.

Weichenrieder, A. (1996), Anti-tax-avoidance provisions and the size of foreign direct investment, International Tax and Public Finance, 3, pp. 67-81.

Wilson, J. (1986), A theory of interregional tax competition. Journal of Urban Economics, 19, pp. 296-315.

Wilson, J. (1999), Theories of tax competition, National Tax Journal, 52, pp. 269-304.

Zodrow, G. and P. Mieszkowski (1986), Pigou, Tiebout, property taxation, and the underprovision of public goods. Journal of Urban Economics, 19, pp. 356-70. 